\title{
Language empowerment in the text of automotive product advertisements on print media in Padang City
}

\author{
Afrini Rahmi*), \\ STKIP PGRI Sumatera Barat \\ *) Correspondences author: Jl. Gn. Pangilun, Gn. Pangilun, Padang Utara, Kota Padang, Sumatera Barat 25173; Indonesia \\ e-mail: rahmi_ririn87@yahoo.com
}

\begin{abstract}
This study against the backdrop of irregularities and problems use of advertising language. Irregularities and ambiguities of meaning will lead to wrong interpretation. This study aims to describe the disclosure of text messages advertising automotive products in the print media in the city of Padang in terms of the use of diction, style, and links the image with advertising messages. Data from the study found, the first proper diction with the concept of criteria, precise sense of value in the ad serves conative / directive / persuasive. Secondly, it was found 11 different style of language used in advertising. 11 kinds of style draws on the poetic function of language. Poetic function is intended effect of beauty in advertising. Third, the research found that images in advertising has three functions to reveal the message, namely as icons, indexes, and symbols
\end{abstract}

Key Words: message, advertising text, automomotive product

Article History: Received: 14/06/2018; Revised: 17/07/2018; Accepted: 14/08/2018; Published: 22/08/2018

How to Cite (MLA $7^{\text {th }}$ ): Rahmi, Afrini. “Language empowerment in the text of automotive product advertisements on print media in Padang City" Hortatori Jurnal Pendidikan Bahasa dan Sastra Indonesia 2.1 (2018): 15-23. Print/Online.

Copyrights Holder: Rahmi, Afrini. First Publication: Hortatori Jurnal Pendidikan Bahasa dan Sastra Indonesia (2018).

This work is licensed under a Creative Commons Attribution-ShareAlike 4.0 International License.

\section{Pendahuluan}

Iklan umumnya berhubungan dengan dunia usaha yang dikelola oleh masyarakat. Iklan biasanya diartikan sebagai usaha manusia dalam menyampaikan gagasan, produk atau jasa, yang ditujukan pada sasaran tertentu, melalui media massa, yang mengharapkan keuntungan tertentu, dan memiliki sponsor yang jelas. Iklan yang memiliki daya tarik termasuk iklan yang berguna untuk memancing tanggapan dari konsumen. Sebuah produk atau jasa wajib memposisikan diri untuk menempatkan citra produk atau jasa ke dalam benak konsumen. Untuk itu, hal-hal spesifik yang perlu mendapatkan perhatian, antara lain, atribut, harga, kualitas, penggunaan, persepsi pemakai, dan kategori produk. Bagian terpenting adalah mencari dan menempatkan posisi khusus dalam pikiran konsumen.

Iklan adalah pesan perusahaan yang bertujuan mempengaruhi persepsi masyarakat terhadap barang yang diiklankan. Oleh sebab itu, iklan ditulis secara kreatif untuk menarik minat konsumen. Jika produk yang diiklankan dikenal masyarakat, maka semakin besar permintaan pasar terhadap produk. Tidak jarang iklan untuk sebuah produk berusaha tampil beda dari yang lain untuk menunjukkan ciri khas produknya. Tujuannya tidak lain adalah agar menarik konsumen sebanyak-banyaknya.

Tujuan tersebut dapat tercapai dengan menyajikan iklan secara menarik bahkan tidak jarang terkesan berlebihan untuk menarik perhatian masyarakat luas. Iklan ditata dengan kreatif, mulai dari pilihan kata, tampilan gambar, dan lain sebagainya. Bahasa yang dipergunakan dalam iklan disusun dengan katakata yang indah, sehingga mempengaruhi pendengar atau pembacanya untuk berbuat seperti yang diharapkan pembuat iklan. Penggunaan bahasa persuasif tersebut menjadi salah satu kekuatan bahasa iklan. Kekuatan bahasa iklan dapat dirasakan halus, sedikit mengajari, bahkan tidak jarang dirasakan sebagai sebuah perintah. 
Iklan menawarkan realitas yang sudah diklarifikasi dan dimuliakan. Jean Baudrillard menyatakan, jika hal ini memicu gejala hiperealitas (keseolah-olahan), yakni situasi di mana realitas runtuh. Realitas yang diseleksi dan direkayasa kemudian ditampilkan di media untuk diyakini oleh audiens sebagai yang lebih nyata dari realitas sebenarnya. (Banyumili, 2009: http://newmedia.kompasiana.com/2009/10/24/keseolah-olahan-iklan-politik/. Diakses tanggal 15Januari 2011).

Kenyataan tersebut dipengaruhi oleh bahasa persuasif iklan yang disajikan. Bahasa persuasif iklan bertujuan menciptakan imej masyarakat terhadap produk maupun jasa yang ditawarkan. Bahkan bahasa persuasif iklan sengaja diciptakan sebagai bentuk kreatifitas tanpa meninggalkan tujuan utama iklan sebagai pemberi pesan kepada masyarakat.

Bahasa iklan disampaikan dengan akrab untuk mendekatkan aspek emosional produk dengan calon konsumen. Tidak jarang jika banyak konsumen yang memilih suatu produk karena kecintaannya, seleranya, kebanggaannya, dan kepercayaannya terhadap produk yang dipilih. Padahal belum tentu produk yang lain cacat atau buruk kualitasnya. Akibatnya, pemahaman konsumen terhadap suatu produk sering ditentukan oleh kemampuan konsumen mengetahui dan mengenal produk. Hal tersebut tidak terlepas dari peran iklan untuk menyampaikan pesan suatu produk.

Bahasa persuasif dalam iklan bertujuan untuk menimbulkan daya tarik bagi konsumen, selain menggunakan gambar dan warna. Bahasa dalam iklan berfungsi ganda. Pertama, untuk memasarkan hasil produksi. Kedua, bahasa iklan sebagai seni kreatif berbahasa yang menimbulkan daya persuasif untuk menyampaikan pesan produk.

Sarana yang paling berperan dalam penyampaian pesan tersebut adalah media massa, salah satunya media cetak berupa surat kabar. Surat kabar adalah salah satu media yang sangat berperan penting dalam komunikasi untuk menyampaikan pesan baik berupa berita, artikel, kolom, maupun iklan. Iklan pada media cetak, selain menggunakan bahasa juga diperkuat dengan gambar.

Surat kabar sebagai media cetak yang banyak memuat iklan mempunyai beberapa keunggulan. Salah satu keunggulan dari media cetak adalah daya jangkau dan edarnya dapat sampai ke pelosok. Iklan pada media cetak termasuk yang paling dicari para pemasang iklan karena tergolong praktis, cepat, dan ekonomis. Iklan pada media cetak disebut dengan iklan tulis. Dinamakan iklan tulis karena iklan pada surat kabar disampaikan kepada khalayak dengan menggunakan bahasa huruf yang tercetak di atas kertas.

Salah satu iklan yang terdapat dalam surat kabar adalah iklan produk otomotif dengan bermacam jenis dan merek yang diciptakan sesuai kebutuhan masyarakat. Produk yang diiklankan disesuaikan dengan perkembangan jaman dan kebutuhan alat transpotasi. Fakta tersebut menciptakan peluang bagi perusahaan otomotif. Saat ini banyak bermunculan merek produk otomotif dengan berbagai model, desain, memberikan kualitas yang bagus dan harga yang cukup bersaing.

Selain menawarkan produk yang berkualitas dan penetapan harga, kemampuan perusahaan dalam mengkomunikasikan produk kepada konsumen melalui kegiatan promosi juga merupakan suatu hal penting. Promosi merupakan kegiatan yang dilakukan perusahaan untuk menonjolkan keistimewaankeistimewaan produk dan membujuk konsumen untuk membeli. Perlu diketahui bahwa betapa bagusnya suatu produk bila konsumen belum pernah mendengarnya dan tidak yakin terhadap produk tersebut, maka calon konsumen tidak akan melakukan pembelian (Novandri, 2010; http://isjd.pdii.lipi.go.id//. Diakses tanggal 11 Desember 2010).

Selain itu, bahasa iklan merupakan salah satu bentuk hasil kreatif para pengiklan, agar konsumen dapat membeli produknya, walaupun bahasanya sudah menyalahi teks dan konteks. Inilah perkembangan dunia kebahasaan saat ini yang semua serba tidak laras, yaitu mempunyai makna ambigu. Misalnya, judul headline berita "Preman Hajar Massa", siapa yang dihajar, preman atau massanya? Ternyata setelah dibaca, yang dihajar adalah premannya. Selain ambigu juga salah pesan. Penyebabnya adalah keteledoran pelaku media dalam memproduksi kata dan kalimat (Hartanti, 2008: http:/gmup.ugm.ac.id/berita/detail/2. Diunduh tanggal 10 Januari 2011).

Contoh lain dapat dilihat dalam bahasa iklan produk otomotif sekarang ini yang sangat bervariatif, tujuannya agar masyarakat tertarik memiliki produk yang ditawarkan pada iklan. Menurut Effendy (2003:156), untuk mengerti makna dalam bahasa surat kabar, pembaca harus menggunakan perangkat mentalnya. Oleh sebab itu, bahasa iklan harus menggunakan bahasa yang lazim dan umum, sehingga pembaca mudah memahaminya. Hal ini berkaitan dengan sifat khalayak surat kabar yang heterogen, yang tingkat pendidikannya tidak sama dan mayoritas berpendidikan rata-rata rendah sampai menengah. 
Salah satu contoh iklan produk otomotif berupa mobil merek Hino Dutro. Bahasa iklan produk otomotif tersebut berbunyi "panjang umurnya". Iklan ini adalah seseorang pemuda yang berdiri di samping sebuah mobil. Permasalahan yang timbul adalah kekomunikatifan pesan bahasa iklan tersebut kepada pembaca dengan bahasa yang demikian. Pesan iklan tersebut tidak akan mudah dimengerti jika dilihat sepintas lalu. Bahasa iklan tersebut lazimnya ditujukan untuk manusia. Namun, pada iklan tersebut tidak secara pasti ditujukan pada suatu objek, baik manusia ataupun produk otomotif berupa mobil. Jika dilihat dari konteks penggunaannya, bahasa tersebut dapat berterima. Namun, jika dilihat dari sudut pandang kaidah bahasa Indonesia yang baik dan benar, bahasa iklan tersebut tidak berterima. Salah satunya dari segi penggunaan pilihan kata. Pilihan kata dalam iklan tersebut tidak tepat karena bermakna ambigu. Pilihan kata dinamakan juga dengan diksi.

Diksi atau pilihan kata merupakan unsur yang sangat penting dalam sebuah komunikasi. Menurut Keraf (2005:22) jauh lebih luas dari apa yang dipantulkan oleh jalinan kata-kata. Istilah ini bukan saja dipergunakan untuk menyatakan kata-kata yang dipakai untuk mengungkapkan suatu ide atau gagasan, tetapi juga meliputi persoalan fraseologi, gaya bahasa, dan ungkapan. Ada tiga ide utama mengenai diksi. Pertama, diksi atau pilihan kata mencakup pengertian kata-kata mana yang dipakai untuk menyampaikan suatu gagasan, bagaimana membentuk pengelompokkan kata-kata yaang tepat, atau menggunakan ungkapan-ungkapan yan tepat, dan gaya mana yang paling baik digunakan dalam suatu situasi. Kedua, pilihan kata atau diksi adalah kemampuan membedakan secara tepat nuansa-nuansa makna dari gagasan yang ingin disampaikan, dan kemampuan untuk menemukan bentuk yang sesuai (cocok) dengan situasi dan nilai rasa yang dimiliki kelompok masyarakat pendengar. Ketiga, pilihan kata yang tepat atau sesuai hanya dimungkinkan oleh penguasaan sejumlah kosakata atau perbendaharaan kata bahasa itu. Pakar lain, Kridalaksana (1993:44) mengatakan bahwa diksi adalah pilihan kata dan kejelasan lafal untuk memperoleh efek tertentu dalam berbicara di depan umum atau dalam karang mengarang.

Diksi adalah pilihan kata seseorang yang perbendaharaan katanya terbatas, akan kesulitan berkomunikasi, baik secara lisan maupun tulis. Persoalan pilihan kata dalam karangan menyangkut kesesuaian penggunaan kosakata yang tepat guna. Kata-kata yang dipakai menunjukkan tingkah laku sosial dan lapisan sosial penggunanya (Thahar, 2008:16-17). Senada dengan hal tersebut, Muharmin (dalam Thahar, 2008:18) berpendapat bahwa diksi yang baik sebenarnya dapat menghasilkan gaya bahasa yang kuat. Ketepatan makna tersebut hendaklah sesuai dengan konsep.

Selain itu, diksi atau pilihan kata dan kejelasan lafal untuk memperoleh efek tertentu dalam berbicara di depan umum atau dalam karang mengarang (Kridalaksana, 1993:44).

Hassanuddin WS. (2002:98) mengatakan bahwa kegiatan memilih kata setepat-tepatnya untuk mengungkapkan suatu gagasan dapat disebut dengan diksi. Sudjiman (dalam Hassanuddin WS., 2002:199) mengatakan bahwa diksi yang baik berhubungan dengan pemilihan kata bermakna tepat dan selaras, yang penggunaannya cocok dengan pokok pembicaraan atau peristiwa. Manaf (2008:141) juga menyimpulkan bahwa pilihan kata berhubungan dengan kesatuan leksikal untuk mengungkapkan gagasan dan kesesuaian kata atau satuan leksikal dengan konteks pemakaiannya.

Pembahasan diksi yang mengandung gaya bahasa berkaitan dengan fungsi bahasa. Menurut Jakobson (dalam Ibrahim, 1995:131), ada enam fungsi bahasa yaitu, emotif, konatif, konteks, pesan, kontak, dan kode. Pertama, dalam fungsi bahasa secara emotif ini pembicara mengarahkan ekspresi langsung dari sikapnya terhadap topik atau situasi. Kedua, fungsi konatif dimaksudkan untuk orang-orang yang diajak bicara bicara. Fungsi ini digunakan untuk bentuk vokatif dan imperatif, meminta orang lain atau menyuruh orang lain melakukan sesuatu. Ketiga, fungsi konteks lebih umum dibandingkan fungsi bahasa yang lainnya. Fungsi konteks lebih menfokuskan pada objek, topik, dan isi yang dimaksudkan dalam wacana. Keempat, fungsi pesan lebih difokuskan untuk tujuan menyampaikan pesan. Kelima, fungsi kontak lebih ditekankan pada pemanfaatan bahasa penciptaan dituasi komunikasi dalam lingkungan sosial. Keenam, fungsi kode lebih diarahkan kepada fungsi kode linguistik itu sendiri.

\section{Metode}


Penelitian kualitatif ini disebut juga penelitian naturalistik karena penelitiannya dilakukan pada kondisi yang alamiah (natural setting), di mana peneliti adalah sebagai instrumen kunci, teknik pengumpulan data dilakukan dengan cara triangulasi (gabungan), analisa data induktif,dan hasil penelitian lebih menekankan pada makna dari pada generalisasi (Sugiyono: 2005:1). Penelitian ini termasuk jenis penelitian kualitatif karena penelitian ini akan menghasilkan data tertulis berupa pengungkapan pesan dalam teks iklan produk otomotif di media cetak Kota Padang. Selain itu juga mengandalkan manusia dalam hal ini peneliti sebagai alat penelitian.

Metode penelitian ini adalah penelitian deskriptif yaitu metode yang digunakan untuk menemukan pengetahuan yang seluas-luasnya terhadap objek penelitian pada suatu saat tertentu. Penelitian deskriptif merupakan penelitian yang bermaksud mengumpulkan informasi mengenai status suatu variabel atau tema, gejala atau keadaan yang ada, yaitu gejala menurut apa adanya saat penelitian dilakukan (Widodo dan Mukhtar, 2000:15). Penelitian deskriptif yang dilakukan menggunakan model analisis isi (content analysis).

Data penelitian ini adalah teks iklan produk otomotif yang terdapat pada empat koran lokal yang ada di kota Padang. Keempat koran lokal tersebut adalah Singgalang, Padang Ekspress, PosMetro dan Haluan. Ke empat koran tersebut dipilih karena merupakan empat koran lokal ternama di kota Padang. Selain itu, koran-koran tersebut banyak memuat iklan produk otomotif dari berbagai perusahaan. Hal ini sesuai dengan salah satu dari tujuh kriteria untuk sampel penelitian kualitatif dengan sumber data nonmanusia. Kriteria tersebut adalah situasi sosial yang relatif banyak memuat informasi tentang domain yang tercakup dalam topik penelitian (Faisal, 1990:59).

Instrumen utama dalam penelitian ini adalah peneliti sendiri sebagai penginterpretasi data. Seperti yang disampaikan oleh Sugiyono (2009:306) bahwa peneliti sebagai key instrument. Oleh karena itu, peneliti berfungsi menetapkan fokus penelitian, memilih informan sebagai sumber data, melakukan pengumpulan data, menilai kualitas data, analisis data, menafsirkan data, dan membuat kesimpulan atas semuanya. Pengertian manusia sebagai instrumen atau alat penelitian di sini tepat karena manusia menjadi segalanya dari keseluruhan proses penelitian (Moleong: 2009:168). Instrumen pembantu adalah berupa wawancara dan angket yang dibagikan kepada sejumlah informan yang telah dipilih. Informan dipilih berdasarkan empat metode yang disampaikan Mahsun (2006:210 - 211) tentang cara pemilihan informan. Salah satunya adalah yang dekat dengan peneliti.

Data penelitian ini adalah data nonmanusia yaitu berupa dokumen. Menurut Faisal (1990:81), dokumen adalah semua jenis rekaman atau catatan sekunder yang relatif baru dan belum terlalu lama, sehingga memiliki aktualitas yang cukup tinggi. Data penelitian ini adalah teks iklan produk otomotif yang terdapat dalam empat koran lokal yang terbit Desember 2010 sampai dengan Februari 2011.

Teks iklan yang dijadikan objek penelitian adalah teks iklan yang di dalamnya terdapat gambar dan banyak memanfaatkan bahasa. Data yang berupa teks iklan tersebut dikumpulkan dengan beberapa langkah berikut. Pertama, data penelitian dikumpulkan dengan cara mendokumentasikan iklan produk otomotif dalam empat media cetak kota Padang yang terbit dari Desember 2010 sampai dengan Februari 2011. Kedua, pencatatan iklan berdasarkan nama produsen, jenis produk dan kode produk. Ketiga, data iklan dalam produk otomotif yang telah diberi kode tersebut kemudian diuraikan lagi berdasarkan bahasa iklan yang ada. Keempat, menyebarkan angket untuk memperoleh data tentang kekomunikatifan pesan dalam iklan. Kelima, melakukan wawancara dengan beberapa informan untuk melengkapi data hasil penyebaran angket.

\section{Hasil dan Diskusi}

\section{Penggunaan Diksi dalam Bahasa Iklan}


Salah satu fungsi bahasa adalah sebagai alat komunikasi. Komunikasi merupakan wujud ekspresi diri untuk menyampaikan yang dipikirkan, dirasakan, dan yang diketahui kepada orang lain. Dengan komunikasi dapat memelajari apa yang ada di sekeliling. Sebagai alat komunikasi, bahasa merupakan saluran perumusan maksud, melahirkan perasaan dan memungkinkan menciptakan kerja sama dengan orang lain. Misalnya,

Mio kasih kejutan...

Sayang kalo terlewatkan...

(Iklan Yamaha Mio)

Diksi kasih kejutan mengisyaratkan bahwa ada orang lain yang diberi kejutan. Diksi tersebut secara tidak langsung menggambarkan hubungan kerja sama. Kerja sama tersebut terjadi antara produsen dengan konsumen. Produsen menjual produknya dan memberikan hadiah kejutan. Konsumen membeli produk yang dijual dan mendapatkan hadiah kejutan seperti yang disampaikan oleh produsen dalam iklannya.

Fungsi bahasa sebagai alat komunikasi dalam kehidupan sehari-hari dapat dimanfaatkan di berbagai bidang kegiatan salah satunya iklan. Bahasa dalam iklan berfungsi sebagai alat komunikasi produsen dengan konsumen. Bahasa yang menarik dalam iklan dimanfaatkan untuk mengenalkan barang atau jasa hasil produksi sehingga konsumen tertarik untuk mencoba atau membeli produk yang ditawarkan. Bahasa dalam iklan dapat berfungsi sebagai media komunikasi dan sebagai sebuah pencipta realitas dalam iklan yang bersangkutan. Bahasa iklan yang dilihat dalam penelitian dilihat dari kedua aspek tersebut. Pertama, sebagai media komunikasi antara produsen dengan konsumen untuk memasarkan produk yang diiklankan. Kedua, sebagai pencipta realitas dalam iklan artinya seseorang bebas menggunakan bahasa untuk menciptakan wacana sendiri untuk tujuan tertentu dalam hal ini penginformasian produk kepada calon konsumen.

Bahasa dalam konteks komunikasi iklan adalah penggunaan kata-kata yang dirangkai untuk mengenalkan suatu produk baik berupa barang maupun jasa kepada konsumen. Kata-kata dalam bahasa iklan bersifat persuasif. Artinya, ata-kata dapat memanipulasi konsumen menjadi alat untuk produsen. Kata-kata yang digunakan membuat konsumen untuk setuju dengan sudut pandang mereka, memberikan apa yang mereka inginkan, melakukan apa yang mereka minta, dan membeli apa yang mereka jual.

Makna yang terkandung dalam bahasa iklan menjadi kekuatan dalam bahasa iklan. Konsumen lebih tertarik dengan kata-kata yang dapat meyakinkan walaupun belum ada pembukian. Kata-kata yang dipergunakan dapat ditinjau dari aspek diksi yang dipgunakan, gaya bahasa yang dipakai, dan pemanfaatan gambar untuk pendukung. Diksi berhubungan dengan konsep ketepatan, kecermatan, dan kesesuaian. Gaya bahasa berhubungan dengan kemampuan menggunakan kata-kata yang indah untuk menarik perhatian konsumen. Gambar dipergunakan untuk pendukung bahasa iklan.

Data hasil penelitian ditemukan sebanyak 107 jenis iklan produk otomotif dalam jangka waktu penelitian yang telah ditentukan sebelumnya. Iklan tersebut terdiri dari dua jenis produk. Pertama, produk otomotif berupa kendaraan roda dua atau motor sebanyak 72 buah iklan. Kedua, produk otomotif jenis kendaraan roda empat sebanyak 35 buah iklan. Peranan bahasa dalam iklan produk otomotif ditinjau dari aspek menarik dan memikat hati, serta kejujuran dalam penyampaian informasi dalam iklan. Aspek menarik dan memikat hati dalam bahasa iklan dapat dilihat dari diksi dan gaya bahasa yang dipergunakan. Diksi dilihat aspek menarik dan memikat hatinya adalah dengan penggunaan diksi yang tepat konsep, tepat nilai rasa, dan tepat konteks. Tepat konsep adalah penggunaan diksi yang dapat mendefinisikan objek secara tepat. Tepat nilai rasa adalah penggunaan diksi yang menunjukkan rasa kesopanan, penghormatan, dan sebagainya. Tepat konteks adalah penggunaan diksi yang sesuai dengan situasi pembicaraan (Manaf, 2008:141). 
Berdasarkan hasil analisis data penelitian ditemukan pemanfaatan diksi sebagai salah satu bagian daya persuasif iklan. Diksi yang dipergunakan dalam iklan mencakup tiga kriteria, yaitu diksi tepat konsep, diksi tepat nilai rasa, dan diksi tepat konteks. Ketiga kriteria diksi tersebut dimanfaatkan untuk kepentingan persuasif pihak pengiklan. Ketiga kriteria diksi tersebut mengarah pada satu fungsi bahasa yaitu fungsi konatif (direktif atau persuasif).

Fungsi konatif/direktif/persuasif tersebut bertujuan menyuruh melakukan sesuatu. Fungsi ini dalam bahasa iklan secara tidak langsung memerintahkan konsumen untuk membeli produk yang ditawarkan. Kata perintah dalam iklan tidak secara langsung dibunyikan dalam teks iklan tetapi disampaikan secara tidak langsung dengan memanfaatkan diksi yang mencakup tiga kriteria di atas.

\section{Penggunaan Gaya Bahasa dalam Bahasa Iklan}

Aspek kedua yang dilihat dari penggunaan bahasa iklan adalah penggunaan gaya bahasa. Gaya bahasa dalam iklan ini dipergunakan untuk memunculkan efek keindahan dan kemenarikan iklan melalui permainan bahasa. Bahasa yang dipergunakan sengaja diciptakan dengan memunculkan interpretasi yang ganda di pikiran pembaca. Tujuannya untuk mmunculkan rasa penasaran sehingga memunculkan rasa tertarik dalam diri pembaca. Gaya bahasa cenderung bermakna konotatif sehingga menimbulkan efek daya khayal. Sesuai dengan yang disampaikan Keraf (2005:114), bahwa menarik dalam hal ini dapat diukur dengan beberapa komponen, yaitu variasi dalam nada, struktur, dan pilihan kata, penggunaan humor yang sehat berarti dapat menciptakan rasa gembira dan nikmat, pengertian yang baik, vitalitas dan daya kahayal. Penggunaan variasi nada dalam bahasa iklan pada merupakan salah satu daya tarik gaya bahasa dalam teks iklan. Pengulangan bunyi yang sama pada akhir teks menciptakan keindahan bunyi. Misalnya,

\section{Borong rejeki \\ di tahun kelinci}

(Iklan mobil Isuzu Elf)

Gaya bahasa dalam iklan tujuannya untuk membuat perbandingan, pertentangan, penegasan, maupun perumpamaan yang berusaha menonjolkan produk. Salah satunya menggunakan majas metafora. Majas ini untuk memunculkan realitas pembanding produk dengan benda lain yang sifatnya sama.

Selain itu, kata-kata yang indah berbentuk gaya bahasa dalam iklan digunakan untuk menarik perhatian konsumen untuk tertarik pada produk yang ditawarkan dan akhirnya membeli produk tersebut. Gaya bahasa yang indah dan mudah diingat menjadi kekuatan dari bahasa yang digunakan dalam iklan. Gaya bahasa disusun dengan merangkai kata-kata yang sifatnya persuasi yang mempengaruhi pikiran, emosi, dan berujung pada tindakan membeli produk yang ditawarkan.

Pemilihan gaya bahasa yang tepat dapat menimbulkan efek keindahan pada iklan yang ditulis. Efek keindahan yang ditimbulkan dari gaya bahasa yag pilih akan berdampak terhadap citra produk yang diiklankan. Selain iu, pemilihan gaya bahasa yang tepat untuk mengiklankan produk dapat membuat orang yang awalnya tidak tertarik menjadi tertarik dan berbuat seperti yang disarankan dalam iklan. Hal tersebut merupakan salah satu bentuk kekuatan sebuah kata dalam kalimat iklan.

Dari data hasil penelitian ditemukan 11 macam gaya bahasa dalam teks iklan produk otomotif. Gaya bahasa tersebut adalah 5 personifikasi, 8 hiperbola, 3 repetisi, 15 aliterasi, 7 hipalase, 5 retoris, 5 asindenton, 2 anafora, 3 polisndenton, 4 metafora, dan 6 sinekdoke pars pro toto. Gaya bahasa terdapat dalam masing-masing teks iklan produk otomotif yang dijadikan objek penelitian. Satu jenis produk bisa menggunakan satu atau lebih gaya bahasa. Gaya bahasa dengan pemilihan kata yang menarik menjadikan produk mudah diingat oleh konsumen. Gaya bahasa 
dalam iklan ini sengaja memilih kata-kata memiliki kekuatan yang berpengaruh terhadap emosi pendengarnya untuk berbuat dan bertindak seperti yang diinginkan oleh produsen. Gaya bahasa dalam teks iklan mengarah pada fungsi kontrol sosial bahasa.

Fungsi puitis bahasa menekankan pada efek keindahan bahasa. Efek keindahan dalam bahasa iklan digunakan untuk menciptakan daya tarik bagi masyarakat. Daya tarik tersebut dapat berwujud perulangan bunyi, perbandingan dengan objek lain, pertentangan, dan perumpamaan. Selain itu penggunaan gaya bahasa dalam iklan secara implisit mengarahkan konsumen menjadi komsumtif tanpa pertimbangan nilai kebutuhan terhadap barang dan jasa yang ditawarkan.

\section{Keterkaitan gambar dengan pesan iklan}

Ikon merupakan suatu tampilan dalam bentuk gambar dan kita dapat melihat bahwa tanda ikonik berhubungan dengan objeknya dengan kemiripan terhadap objek tadi. Jadi tanda ikonik termasuk tanda linguistik dan tanda yang berbentuk gambar yaitu lukisan, gambar dan foto. Dalam iklan-iklan mobil, biasanya terlihat foto dari berbagai jenis mobil yang tersedia. Tanda tadi dapat dilengkapi dengan pemandangan yang berhubungan dengan produk yang ditawarkan dalam iklan yang ditampilkan. Pada dasarnya ikon merupakan tanda yang mampu menggambarkan ciri utama sesuatu objek yang meskipun objek tersebut tidak hadir. Dalam iklan mobil hampir selalu melihat gambar mobil yang merupakan ikon dari mobil yang ditawarkan. Gambar mobil merupakan ikon yaitu tanda yang berupa gambar atau foto yang dirujuk dari bendanya.

Dari hasil penelitian ditemukan bahwa pada masing-masing teks memiliki ikon. Ikon yang terdapat dalam masing-masing teks iklan merujuk pada benda atau objek yang terdapat dalam tanda. Gambar mobil sebagai ikon untuk menunjukkan benda otomotif berupa mobil. Gambar sepeda motor menjadi ikon untuk kendaraan otomotif berupa sepeda motor. Contohnya, pada teks iklan Nissan March terdapat 9 buah foto dengan latar mobil di berbagai tempat. Ekspresi senang dan ceria ditampilkan pada model masing-masing foto. Teks iklan tersebut adalah easy. Hal tersebut menunjukkan hubungan produk yang ditawarkan mudah untuk dikendarai dan di bawa kema pun juga. Ikon dalam teks iklan ini mengungkapkan kekomunikatifan pesan iklan dilihat dari kesamaan gambar dengan produk yang ditawarkan.

Indeks adalah tanda yang berdasarkan relasi sebab dan akibat atau koneksi gabungan antara tanda dan objeknya. Tanda yang hadir secara asosiatif akibat terdapat hubungan ciri acuan yang sifatnya tetap. Kata rokok misalnya memiliki indeks asap. Kata mobil memiliki indeks asap knalpot kendaraan. Kata yang memiliki hubungan indeksikal masing-masingnyamemiliki ciri utama secara individual. Ciri tersebut antara satu dengan lain berbeda dan tidak dapat saling menggantikan. Ciri utama pada mobil tidak dapat menggantikan ciri pada asap knalpot. Pada penelitian ini yang menjadi indeks dalam teks iklan adalah gambar objek dalam teks iklan yang menjelaskan satu dengan lainnya.

Dari hasil penelitian ditemukan adanya indeks yang berfungsi untuk mengungkapkan pesan iklan. Indeks dalam iklan berfungsi untuk menunjukkan hubungan antara gambar dengan sifat dari yang dilambangkan. Jika dilambangkan seorang binaragawan dengan otot yang besar indeks kekuatan dan ketangguhan. Jadi, produk tersebut memiliki kekuatan yang tangguh. Gambar gedung bertingkat adalah indek kota metropolitan menggambarkan kemewahan. Jadi produk yang ditawarkan adalah produk yang menunjukkan citra kemewahan. Hal tersebut menunjukkan sebab dari lambang yang mengakibatkan akibat dari lambang tersebut.

Simbol diartikan sebagai tanda yang mengacu pada objek tertentu di luar tanda itu sendiri. Hubungan antara simbol sebagai penanda dengan petanda (sesuatu yang ditandakan) bersifat konvensional. Status merupakan simbol misalnya profesor, dokter, pengacara, bankir dan pengusaha memiliki status yang baik dan ini merupakan simbol dari kesuksesan hidup. Dalam pandangan banyak orang simbolisasi mobil merupakan kebutuhan pokok, ini merupakan 
keharusan untuk menampilkan kesuksesan secara proporsional. Simbol dapat dipahami jika seseorang sudah mengerti arti yang telah disepakati sebelumnya. Simbol juga meliputi apa yang dirasakan atau dialami, menggigil umpamanya dapat diartikan sebagai simbol dari ketakutan, meneteskan air mata simbol dari kesedihan dan tertawa simbol dari kegembiraan atau ejekan. Lambang bunyi juga merupakan simbol. Sebuah simbol mengacu pada objeknya bukan karena kemiripan atau hubungan sebab antara objek dan tandanya tetapi berdasarkan kesepakatan sosial. Kata merupakan bentuk dari simbol karena hubungan kata dengan dunia acuannya ditentukan berdasarkan kaidah kebahasaannya. Jadi Simbol dapat dipahami jika seseorang sudah mengerti arti yang telah disepakati sebelumnya. Sebuah simbol mewakili sesuatu yang lain, dan hubungan itu tidak bisa melampaui apa yang telah ditetapkan.

Dalam iklan merek dagang merupakan simbol. Mercedes melambangkan keanggunan, kemewahan dan prestis.. Dalam penelitian ini 'Pick-up' adalah simbol mobil dengan bak terbuka untuk angkut barang. 'Truk' simbol mobil dengan bak terbuka untuk angkut barang dengan ukuran yang lebih besar dari pik-up. 'Sedan' mobil dengan tempat duduk untuk empat sampai lima orang. 'SUV' mobil yang biasanya untuk berlima dengan bagian belakang untuk muat barang bawaan, tapi ada juga yang dibuat untuk bertujuh. 'MPV' mobil dengan kapasitas 7 sampai 8 orang penumpang, sedikit lebih besar dari SUV. Untuk kendaraan roda dua, gambar seorang pembalap merupakan simbol dari kecepatan. Sepeda motor dengan warna cerah merupakan simbol dari keceriaan. Gambar sepeda motor trail merupakan simbol dari ketangguhan di segala medan.

\section{Simpulan}

Berdasarkan hasil penelitian yang telah dilakukan dapat disimpulkan tiga hal. Pertama, penggunaan bahasa dalam sebuah iklan memanfaatkan diksi atau pilihan kata untuk mengungkapkan pesan meliputi tiga kriteria ketepatan, yaitu tepat konsep, tepat nilai rasa, dan tepat konteks. Ketiga kriteria diksi tersebut membentuk karakterisitik bahasa iklan yang berfungsi konatif/direktif/persuasif. Diksi yang tepat konsep dalam iklan dipergunakan untuk memberitahukan tentang penawaran harga produk, sistem pembayaran, hadiah pembelian, dan harga produk dengan sistem kredit. Diksi dengan kriteria tepat konsep ini digunakan sebagai salah satu strategi daya tarik bagi calon konsumen. Konsumen cenderung lebih memilih produk yang lengkap dan jelas informasinya. Diksi tepat nilai rasa dalam iklan produk otomotif menunjukkan kehalusan, kesantunan, penghormatan dan penghargaan penutur (produsen) terhadap calon konsumen. Diksi tepat konteks adalah penggunaan nilai rasa yang sesuai dengan situasi pembicaraan. Produsen berusaha menciptakan persepsi bahwa hubungan yang dekat dengan menyejajarkan posisi antara konsumen dan produsen dengan menciptakan hubungan emosional yang erat. Hubungan emosional antara produsen dengan konsumen salah satunya melalui diksi yang menarik.

Kedua, penggunaan gaya bahasa yang menarik dalam teks iklan. Dari data hasil penelitian ditemukan 11 macam gaya bahasa dalam teks iklan produk otomotif. Dari 11 macam gaya bahasa yang ditemukan membentuk karaktersitik bahasa iklan yang berfungsi puitis. Fungsi tersebut mertujuan menciptakan efek keindahan bahasa iklan agar masyarakat tertarik dengan produk yang diiklankan. Gaya bahasa tersebut adalah 5 personifikasi, 8 hiperbola, 3 repetisi, 15 aliterasi, 7 hipalase, 5 retoris, 5 asindenton, 2 anafora, 3 polisndenton, 4 metafora, dan 6 sinekdoke pars pro toto.

Ketiga, selain menggunakan bahasa, iklan juga menggunakan gambar untuk pengungkapan pesan. Dari hasil penelitian ditemukan bahwa gambar dalam iklan memiliki tiga fungsi untuk mengungkapkan pesan, yaitu sebagai ikon, indeks, dan simbol. Gambar sebagai ikon dalam iklan untuk menunjukkan jenis produk yang ditawarkan. Gambar sebagai indeks dalam iklan untuk menunjukkan kemampuan atau peforma produk yang ditawarkan. Gambar sebagai simbol dalam iklan untuk menunjukkan merek dagang dan fungsi produk yang ditawarkan.

\section{Ucapan Terima Kasih}


Terima kasih penulis ucapkan kepada semua pihak yang telah membantu penulis dalam proses penulisan artikel ini.

\section{Daftar Rujukan}

Banyumili. "Keseolah-olahan Iklan Politik". (http://new-media.kompasiana.com/2009/10/24/keseolaholahan iklan-politik/), 2009. Diakses tanggal 15 Januari 2011.

Effendy, Onong Uchjana. Ilmu Komunikasi: Teori dan Praktek. Bandung: Remaja Rosdakarya, 2003. (Print)

Effendy, Onong Uchjana. Dinamika Komunikasi. Bandung: Remaja Rosda Karya, 1986. (Print).

Faisal, Sanapiah. Penelitian Kualitatif: Dasar-Dasar dan Aplikasi. Malang: YA3, 1990. (Print).

Hartanti, Lisa Esti Puji. "Bahasa Indonesia=Bahasa Iklan". http://gmup.ugm.ac.id/berita/detail/2, 2008. Diakses tanggal 10 Januari 2011.

Hasanuddin WS. Membaca dan Menilai Sajak. Bandung: Angkasa, 2002.

Ibrahim, Abdul Syukur. Sosiolinguitik: Sajian tujuan, pendekatan, dan problem. Terjemahan. Surabaya: Usaha Nasional, 1995. (Print)

Keraf, Gorys. Diksi dan Gaya Bahasa. Jakarta: Gramedia, 2005. (Print)

Kridalaksana, Harimurti. Kamus Linguistik. Jakarta: Gramedia, 1993. (Print).

Mahsun. Metode Penelitian Bahasa: Teori, Strategi, Metode, dan Tekniknya. Jakarta: Raja Grafindo, 2006. (Print).

Manaf, Ngusman Abdul. Sintaksis Bahasa Indonesia. Padang: UNP Press, 2000. (Print)

Manaf, Ngusman Abdul. Semantik: Teori dan Terapannya dalam Bahasa Indonesia. Padang: Sukabina Offset, 2008. (Print).

Moleong, Lexy. J. Metode Penelitian Kualitatif: Edisi Revisi. Bandung: Rosda Karya, 2009. (Print).

Novandri, Made. "Analisis Pengaruh Kualitas Produk, Harga, Dan Iklan Terhadap Keputusan Pembeliaan Sepeda Motor Yamaha Pada Harpindo Jaya Cabang Ngaliyan". Jurnal Penelitian Online http://Isjd.Pdii.Lipi.Go.Id//, 2010. Diakses tanggal 10 Desember 2010.

Padang Ekspress. Edisi 10 Mei 2010.

Sugiyono. Memahami Penelitian Kualitatif. Bandung: Alfabeta, 2005. (Print).

Thahar, Harris Effendi. Menulis Kreatif.: Panduan Bagi Pemula. Padang: UNP Press, 2008. (Print) 